\title{
Staging Invisibility in English Early Modern Drama
}

Sometime after 3 April 1598 Philip Henslowe laid out part of a $£ 310$ s sum on 'a robe for to goo invisibell'. Not withstanding his good fortune in locating this elusive garment, stage conventions of invisibility are earlier, more varied, and considerably more sophisticated than this robe itself. By the time that Henslowe bought his robe to go invisible, he had at hand any number of stage conventions for performing invisibility. 'Medieval' biblical plays, both in England and on the Continent, left a rich tradition of stage invisibility, a performance heritage which did not end in England until the mid-1570s and thus easily spanned its way into the Elizabethan public theatres. Among the four surviving 'cycle' texts, only two of which now are acknowledged as cycles, a remarkable number of pageants record appearances, disappearances, invisibility, vanishing, and some of the devices or techniques used to accomplish these feats. Additionally, continental eyewitness accounts supply detailed narratives of what literally was observed by way of 'magical' or 'miraculous' appearances and disappearances.

A brief explanation about the structure of this present study may be helpful to readers. Although the piece discusses pre- and post-Elizabethan drama, with Henslowe's 1598 purchase of 'a robe for to goo invisibell' as the dividing line, it navigates the shoals of both periods without signposting specific dates for the pageants in part because its myopic focus is on staging invisibility across four centuries of early English drama and in greater part because pageant composition dates are unknown or ambiguous. The unique York Cycle manuscript was copied between 1463 and 1477; the Chester Cycle, as 'cycle', survives in five manuscripts copied between 1591 and 1607; the N-Town manuscript main scribe's hand has been placed sometime between the mid-fifteenth and early sixteenth centuries; the compilatio Towneley manuscript's main hand presently seems to hover between early- and midsixteenth century; and the scribe for The Conversion of St. Paul apparently dipped his quill in the first quarter of the sixteenth century. The original 
pageant texts most likely date much earlier than the extant copies, but for the sake of clarity this present study resists temptations to fashion an evolutionary sequence, instead focusing on the various techniques of staging invisibility.

This study considers six 'categories' or 'techniques' of invisibility, illustrating them somewhat randomly from the pre-Elizabethan English pageants and then from continental accounts. First come verbal markers of invisibility - announcements, declarations, observations, charms, spells — spoken stage claims that someone or something cannot be seen, no longer can be seen, or cannot see. Towneley Pageant 27, 'Peregrini', is typical: Jesus appears 'in apparatu pergrini [sic]'; the apostles prepare a table; 'Tunc recumbent, et sedebit Iesus in medio eorum; tunc benedicet Iesus panem et franget in tribus partibus, et postea euanebit ab oculis eorum' [Then they shall recline, and Jesus will sit between them. Then Jesus shall bless the bread and break it into three pieces, and afterwards he shall vanish from their sight]. Reinforcing how suddenly Jesus vanishes, Luke exclaims, 'Wemmow! where is this man becom,/ Right here that sat betwix vs two?' and Cleophas echoes the mystery: 'When went he hens, whedir, and how — / What, I ne wote in warld so wyde!'

Jesus' disappearance leaves 'this greatt vanyte' where he had been, marking a quick, stealthy, unobserved exit, surely not via a windlass 'as at Coventry, where the Drapers continually incur expenses for the device', as Towneley editors A.C. Cawley and Martin Stevens suggest. ${ }^{1}$ A windlass's lifting platform loaded with a full-sized man on a precariously balanced pageant wagon full of apostles would allow anything but a quick and stealthy exit. We find another type of verbal marker in Towneley Pageant 13, 'The Second Shepherds' Play', in which Mak first makes a spell starting with a false benediction ('Fro my top to my too, Manus tuas commendo, Poncio Pilato; Crystcrosse me spede!'). He then draws around the three sleeping shepherds a circle round as a moon so that they lie stone-still until he has done, and casts the spell: 'On hight,/ Ouer youre heydys, my hand I lyft./ Outt go youre een! Fordo youre syght!'

Physical markers of invisibility are less easy to detect textually, but they include gestures, blocking, and movements of actors suggesting that they either cannot see - or cannot recognize, often through disguise - the invisible actor. The N-Town Play 37, 'Resurrection', for example, costumes Jesus as a 'jentyl gardener' who simply appears to Mary Magdalene as she mourns the empty sepulchre. ${ }^{2}$ N-Town Play 38, 'Cleophas and Luke: The Appear- 
ance to Thomas', has Jesus disguised as a pilgrim overtake the two apostles on the road: 'Well ovyrtake, ze serys in-same./ To walke in felachep with zow I pray'. Cleophas describes what we see - 'Sere, methynkyth pu art a pore pylgrym/ Here walkynge be piselfe alone' — and as adroitly as he has joined them, 'Hic subito discedat Christus ab oculis eorum'. Another possible disguising, I have argued elsewhere, is Deus's initial appearance to Noah in the Towneley 'Flood'. ${ }^{3}$ Surely the Towneley Deus is anthropomorphic: his monologue divides easily into beats which express shifting emotions, and his notion of ship building is less than omniscient as he piles detail upon detail in a most peculiar order. ${ }^{4}$ Noah does not recognize Deus and must ask his name; this clue suggests that Deus wears a human disguise, perhaps appearing cloaked as a pilgrim in a bit of New Testament figurative foreshadowing.

Perhaps the most spellbinding use of physical invisibility markers occurs in Towneley Pageant 26, 'Resurrection', a remarkable dramatic rendering of Nottingham alabaster iconography, Christ's 'Words from the Cross', and the conventional Quem Queritis? The focal landscape shifts among tomb chest, sleeping soldiers, risen Christ, the three Marys, two angels, the soldiers' interlude, and Mary Magdalene's return. Only Christ and the audience are able to see - and perceive - the entire play: to varying degrees, all of the human actors are blind. Angels singing 'Christus resurgens' cast the pageant's first spell, at which Christ almost must rise out of the tomb chest, which is surrounded by four sleeping soldiers on the ground. ${ }^{5}$ Visible only to the audience, Jesus graphically directs his 120-line 'Words from the Cross' to that audience as he displays his wounds in a monologue of affective piety eerily similar to the Almondbury, West Riding All Saints' nave carving. ${ }^{6}$ How he leaves after the monologue is not clear. Possibly, the resurrection tomb is a juggling box with false bottom, 'wherein manie false feats are wrought'; alternatively, the tomb cover lifts by way of the rope and pulley mechanism described in the late fifteenth-or early sixteenth-century Volume of Secrets of a Provençal Stage Director's Book. ${ }^{7}$ Another possibility is that the play covers his exit by distracting the audience through the combination of Christ's moving monologue, the arrival of the Marys, and the two angels' mysterious appearance in white clothing where 'the stone' has been pushed away. The women then depart, the soldiers awake, and the imaginative playwright inserts an 'interlude' in which they attempt explanations to Anna, Caiphas, and Pilate. Following the interlude, the audience focuses on Mary Magdalene with Jesus invisible as a gardener who by some dramatically effective means reveals himself: 'Mary, thou sekys thy God, and that am I'. 
The Towneley 'Resurrection' illustrates a third category of invisibility: prescribed and proscribed performance areas. The actors' words tell us how the platea - be it wagon, ground, great hall, or Globe - is geographically defined. Whether one door is France and the other is England, whether the wagon is earth and the ground hell, whether everyone inside the circle is asleep to sheep theft and everyone outside the circle watching the thief, the audience creates the conventions of invisibility. The central question, as Alan Dessen so astutely analyzes, concerns whether the audience is fooled or collaborative; in terms of medieval English drama, this a very large subject for a very large other day. ${ }^{8}$ Clearly in medieval religious drama, the audience cannot be fooled by invisibility because the audience knows the scriptural or liturgical story. The audience, however, can (and should) be delighted by how adroitly the invisibility is accomplished, and it most certainly can be moved by spectacular effects.

A fourth category of invisibility, similar to prescribed playing spaces in that it relies on audience acceptance of the convention, involves a variety of instruments used to render actors invisible. The problem for scholars is that unless such objects are specified in the text, their presence goes unnoted, and because medieval religious drama is 'miraculous' rather than 'magical', instruments are rare. Herbs and precious stones can possess such magic, although 'the invisibility stone' was negotiable:

No one gem was ever singled out for its unique combination of magical, therapeutic, and apotropaic characteristics. Instead, marvelous powers were ascribed to a variety of precious stones, enabling them to heal a multitude of physical and mental ailments, including depression, insanity, and attacks of phantasms and nightmares. Like their herbal and animal counterparts, precious stones were deemed capable of warding off demons and protecting the bearer from enchantments; they could help bring triumph in combat or a judicial case, provide a means for testing faithfulness or virginity, render their owner invisible, and even resuscitate the dead. ${ }^{?}$

The Folger Consort's December 2007 production of the Towneley Secunda Pastorum gave Mak a large sprig of rosemary to wave over the sleeping shepherds. Dessen notes that in Dekker's 1599 Old Fortunatus 'figures suddenly disappear by means of a magical wishing hat' and that in The Puritan, or the Widow of Watling Street (1606), foolish young Edmond believes that he is made 'invisible' by a wand flourished three times over his head. Leslie Thom- 
son notes Smirke's stealing and wearing a ring which renders him invisible in the 1619 play Two Merry Milkmaids. ${ }^{10}$

Fifth in performing stage invisibility are the numerous physical devices so consistently underestimated by those who begin their study of English early modern drama in the 1580s. Whether medieval plays consistently used such devices in performance is debatable; that they were able to create them is unarguable. ${ }^{11}$ Chester Play 20, The Taylors' 'Ascension', is quite specific, as David Mills has outlined:

The stage-direction at line 96 [Tunc adducet discipulos in Bethaniam; et cum pervenerit ad locum, ascendens dicat Jesus, stans in loco ubi assendit. Dicat Jesus, 'Data est mihi omnis potestas in caelo et in terra'] makes it clear that Jesus is to stand in a specific place for the Ascension, strengthening the sense that the waggon contained a lifting device which would raise him in stages from the floor of the waggon to an upper level. Midway is an area 'as if above the clouds' which he reaches at the end of the Ascendo. At this point, or earlier, the upper level of heaven opens to reveal the angels. When Jesus reaches heaven, the two angels evidently replace him on the lift and descend to the midway-level to address the disciples ['Viri Gallilei, quid aspicitis in caelum?' sung to the apostles — Ye men of Galilee, why stand ye gazing up into heaven?]. ${ }^{12}$

Winches, pulleys, traps, heavens, wires, other hoisting devices, and concealing devices, particularly clouds: documentation of their fabrication and use in performance is plentiful, particularly in Continental records. ${ }^{13}$ A detailed account of cloud construction for a movable image of the Holy Ghost, found in a surviving 1520 Ripon Minster fabric roll, suggests that the English, even outside London, were not unfamiliar with cloud construction for dramatic effect:

Et de 78s. receptis de denariis collectis per garciones villae Ripon hoc anno et datis tam ad novam cellaturam parcell' del Rooff in navi ecclesiae praedictae quam pro nova factura cujusdam nebulae pro lee Holy Goost, ut patet indentura inter dictos garciones et istum computantem confecta super hunc compotum ostensa. Summa, $78 s \ldots$. De quibus allocatus ei $18 s$. $3 \frac{1}{2} 2$. pro tot denariis per ipsum solutis pro nova factura cujusdam nebulae in navi ecclesiae praedictae, ut in opere carpentr' pro Spiritu Sancto in eadem ascendendo et discendendo in die Ascensionis Domini et Pentecostes; empcione stuffurae pro le paynting, cum vadimonia Thomae Payntour pro pictura praedicti operis hoc anno. ${ }^{14}$ 
Finally, the medieval heritage of stage invisibility bequeathed numerous techniques of deception and distraction, from simple blocking to elaborate spectacle using sound, light, fire, and costume. The York Curriers' 'Transfiguration' produces blinding light when Christ is transfigured between Moses and Elijah: Peter loses his might and James waxes weak in the illumination, which garbs Christ in a snow-white robe and gilded mask. Clouds descend to cover the vision, and God the Father speaks out of a cloud while Jesus, alone, is restored to the apostles' sight. The play achieves further wonder and distraction through 'a hideous noise', which John affirms stunned him more than the illumination. ${ }^{15}$ Likewise in the York 'Incredulity of Thomas' and 'Pentecost' pageants, the light surrounding Jesus is so bright that it has maddened and blinded the witnessing apostles. Doubtless, such pyrotechnic flashes of fire or sustained illumination are real and not imagined, as the Chester 'Pentecost' pageant's stage direction details:

Tunc Deus emittet Spiritum Sanctum in spetie ignis, et in mitendo cantent duo angeli antiphonam 'Accipite Spiritum Sanctum; quorum remiseritis peccata, remittentur eis' etc. Et cantando projecient ignem super apostolos. Finitoque Angelus in caelo dicat. [Then God shall send out the Holy Spirit in the form of fire, and as it is sent, two angels shall sing the antiphon ... And as they sing they shall throw fire upon the apostles. And when this is done the (first) angel in Heaven shall speak.] ${ }^{16}$

Equally real are the pyrotechnics accompanying Belyall and Mercury in the Digby Conversion of St. Paul: 'Here to enter a dyvel wyth thunder and fyre ... Here pei shal vanyshe away wyth a fyrye flame, and a tempest'. ${ }^{17}$ Casting 'a mist' to cover vanishings as 'in Histriomastix where "Pride casts a mist" and then five or more figures "vanish off the Stage" may be metaphoric, although one would think that either the sprayed stuff of stage tempests or cast 'fire' coloured to look like 'mist' could effectively obscure vanishings. ${ }^{18}$

As I have written at length elsewhere, some of the most spectacular effects of visibility and invisibility, miracle and magic, are connected with the Virgin Mary plays. ${ }^{19}$ The 1439 Florence Annunciation and Ascension, detailing what can happen when all six categories are displayed together, is too extraordinary to omit here. According to the eyewitness account of Abramo, a Russian bishop in Florence for the Ecumenical Council, 'heaven' is a scaffold at the entrance to SS. Annunziata Church, very high up and $10 \frac{1}{2}$ feet square with God's throne rising above the platform; 175 feet away, in the middle of 
the church, is a stone platform on columns 21 feet high and 171/2 feet deep. Stretching from the stone platform to the heaven scaffold are five thin but strong ropes; two of them are fastened on the left side near the Virgin's bed and seat with the other three fastened precisely to the centre of the platform. Following extensive activity by the seven heavens, their circular platforms illuminated by 'a thousand lighted oil lamps on them' to represent 'inextinguishable angelic light'; the presence of God the Father 'surrounded by many children artfully arranged'; the sounds of angel musicians; and a half-hour dispute among the four prophets, the Annunciation proper begins as

the curtains of the upper scaffold open and from there comes a volley of shots imitating Heaven's thunder, and the Prophets with their scrolls are not seen again. Up on the scaffold is God the Father surrounded by more than five hundred burning lamps which revolve continually, going up and down. Children dressed in white, representing the angels, surround him, one striking the cymbals, others playing flutes or citterns in a scene of joyful and inexpressible beauty. After some time, the angel sent by God descends on the two ropes already mentioned to announce the conception of the Son. The angel is a beautiful, curly-headed youth, dressed in a robe as white as snow, adorned with gold, exactly as celestial angels are to be seen in paintings. While he descends he sings in a low voice, holding a branch ... in his hand. The descent is effected in this way: behind him there are two small wheels secured, invisible from below because of the distance, into which the two ropes fit, while some people who cannot be seen stand up above and by means of the third very thin rope lower and lift up the angel.

Even more stunning are the moment of the Incarnation and Gabriel's ascent, as

a fire comes from God and with a noise of uninterrupted thunder passes down the three ropes towards the middle of the scaffold, where the Prophets were, rising up again in flames and rebounding down once more, so that the whole church was filled with sparks. The angel sang jubilantly as he ascended, and moved his hands about and beat his wings as if he were really flying. The fire poured forth and spread with increasing intensity and noise from the high scaffold, lighting the lamps in the church but without burning the clothes of the spectators or causing any harm. When the angel arrives back at his point of departure the flames subside and the curtains close again. ${ }^{20}$ 
Henslowe's 'robe to goo invisibell' perhaps pales in comparison, but despite its rich medieval heritage, its specificity remains elusive. As Dessen and Thomson note, 'although invisibility plays a significant role in a range of plays [from 1580 to 1642], the term invisible is found only five times, three of them in Tempest. ${ }^{21}$ The term spirit, 'a figure in the same general category as a devil or fury, typically associated with the underworld and supernatural events', tells us that 'invisible spirits play tricks' — but not how their feats are accomplished. For vanish, 'the roughly twenty examples involve either (1) a sudden disappearance by means of a stage trick or (2) a fictional situation where a disappearance is important for the narrative but the playgoer actually sees one or more figures exit'. Dessen devotes an entire chapter of Recovering Shakespeare's Theatrical Vocabulary to the stage direction 'vanish', for which there are eight instances in Shakespeare. As Dessen notes, his 'purpose in singling out such scenes is to pose the questions ... (1) what would the original playgoers have seen at such moments? (2) how can we tell? and (3) so what?'

Dessen's chapter 'on vanish' usefully raises these and other perceptive questions, but on several matters I would take a more whimsical, perhaps even childlike approach to the stagecraft of vanishing. Making objects and people vanish or turning them invisible is play, fun, cleverness, as the long and abundant history of payments to travelling prestidigitators attests. ${ }^{22}$ Why ever would stage folk not want to display their skills to out-Herod Herod in the spectacle line? When Dessen writes that ' $[\mathrm{m}]$ ost of the medieval vanish effects, however, are linked to Jesus's sudden departures from Mary Magdalen or the disciples' and states that he finds such moments 'hard to imagine as verisimilar in the original productions', I find the converse: of course Christ's departures are from the Magdalene and apostles, as laid down in the story line, but they need be no less visibly miraculous on that account. Likewise, when the medieval capacity for flame, thunder, smoke, fire, and light are so well documented, why would performers shy away from producing 'real' stage mist, fog, or smoke? I rather would draw a theoretical line between verisimilar and fictional where Shakespeare draws it in The Tempest. The banquet itself — the word means an English dinner's final course of sweetmeats and dainties, light, airy, and in part artificially fabricated - can be danced in ('Enter several strange shapes, bringing in a banquet, and dance about it with gentle actions of salutations; and, inviting the King, etc., to eat, they depart') and scooped out ('Enter Ariel, like a harpy, claps his wings upon the table, and with a quaint device the banquet vanishes'). ${ }^{23}$ The empty table, however artistically 
addressed ('to soft music, enter the shapes again, and dance, with mocks and mows, and carrying out the table'), is too heavy for magic or miracle. ${ }^{24}$

Henslowe's Diary entry, made some time after 3 April 1598, records that he 'Bowght a robe for to goo invisibell' and 'Bowght a gown for Nembia' to the total sum of $£ 310$ s. $^{25}$ The first problem, no surprise in English early modern drama, involves terminology, namely the meaning of 'robe' versus 'gown'. From both the Oxford English Dictionary and surviving inventories, one infers that robes connote 'robes of ceremony', usually outer garments and perhaps synonymous with 'mantles'. Often long, loose outer garments reaching to the feet or ankles, robes can be worn in virtue of and betokening a particular rank, calling, condition, or office, such as the 'long robe' - the dress of the legal or clerical profession. 'Gown', a term used for the dress of both men and women, connotes a loose flowing upper garment worn as an article of ordinary attire, extending to 'dress' for women and 'nightgown' or 'dressing gown' for men. Although the $O E D$ sees these terms as interchangeable - eg, academic robe or academic gown - in the inventories (and in Shakespeare) robes are far more rare than the more casual gowns. ${ }^{26}$

How Henslowe divided his $£ 3$ 10s between 'invisibell robe' and 'Nembian gown' cannot be guessed, except to hazard that the robe is long, the gown short. Even that guess is next to useless for assessing the quantity of cloth required, for the inventories are parsimonious on this type of information: sometimes the cost of a garment is given, sometimes the amount of fabric purchased, but seldom do the two data rest in one extant record. In 1518 Henry VIII's long cloak of 'right crimson satin' took fourteen and a half yards at a fabric cost of $£ 13$; a velvet nightgown required twelve yards; a glaudekin (long gown) fifteen yards of black velvet; and a gabardine, a long coat with wide sleeves, only four yards, which suggests a very narrow cut or a very short person. ${ }^{27}$ For Elizabeth's 1558 coronation mantle (robe) and kirtle, "Clothe of golde and silver tissue" had been kept from Mary's coronation in 1553 and altered: the alterations (four yards of "Clothe of Tishewe the grounde golde and Tyshewe Sylver"), which cost $£ 4$ a yard, were delivered for the alterations to the kirtle. This [fabric] was $£ 2$ a yard cheaper than the original materials and probably had less metal thread in it. It would therefore have been lighter in weight, and more pliable'. ${ }^{28}$ Although looking in Henry VIII's or Elizabeth's inventories for a robe 'to goo invisibell' in seems a bit daft, the unprinted, unregal testamentary inventories are even less helpful on yardage or garment cost. 
A second major challenge in assessing Henslowe's robe is that precious little English clothing from the period has survived and the early books on tailoring 'are all of Spanish origin. In 1580 the first edition of Libro de Geometria, pratica y traça by Juan de Alcega was printed in Madrid. This was followed by Diego de Freyle's Geometria, y traça para el oficio de los sastres, printed in Seville in 1588. The second edition of Alcega's book appeared in 1589 and in 1618 Francisco de la Rocha Burguen produced Geometria, y traça perteneciente al oficio de sastres, which was printed in Valencia'. ${ }^{29}$ Relying on English images - portraits, miniatures, engravings - as literal costume guides carries its own dangers, the late Janet Arnold repeatedly warned, as artistic license distorted the proportions. ${ }^{30}$ So, our 'robe to goo invisibell': was it English or foreign style? long or short? full or narrow? flexible or rigid? In 1575 Emmanuel van Meteren, a merchant of Antwerp who settled in London and served as Dutch consul in England from 1583-1612, commented that ' $[\mathrm{t}]$ he English dress in elegant, light, and costly garments, but they are very inconstant and desirous of novelties, changing their fashions every year, both men and women'. Fynest Moryson's 1617 Itinerary account confirms:

All manners of attire came first into the City and Countrey from the Court which being once received by the common people, and by very Stage-players themselves, the Courtiers justly cast off, and take new fashions, (though somewhat too curiously); and whosoever weares the old, men looke upon him as upon a picture in Arras hangings. For it is proverbially said, that we may eate according to our owne appetite, but in our apparell must follow the fashion of the multitude, with whom we live. But in the meane time it is no reproch to any, who of old did were those garments, when they were in fashion. ${ }^{31}$

As founding Wardrobe Mistress of the Globe, Jenny Tiramani, notes, '[there is surviving evidence from the period which indicates that Shakespeare and his fellow actors often performed in contemporary dress. Thomas Platter, a Swiss visitor to the Globe in 1599, wrote that "the actors are most expensively and elaborately costumed, for it is the English Usage for eminent Lords or Knights at their decease to bequeath and leave almost the best of their clothes to their serving men, which it is unseemly for the latter to wear so they offer them for sale for a small sum to the actors"' ${ }^{32}$ Stage apparel could be of sumptuous quality: Tiramani cites Edward and John Alleyn's 'blacke velvet cloake, with sleves ymbroidered all with silver and golde, lyned with black sattan striped with golde', acquired for the staggering sum of $£ 2010$ s 
0d. For the Diary item immediately below the infamous 'invisibell robe' and 'Nembian gown' entry, Henslowe lays out $£ 7$ for 'a dublett of whitt satten layd thicke with gowld lace, and a payer of rowne pandes hosse of cloth of sylver, the panes layd with gowld lace'.

From these last two items, among others, we can infer that Henslowe was relatively undeterred by costume expense, although the 'invisibell robe' was not that pricey. Thus arguments that certain fabrics (tissues, fancy fabrics, cloth of gold or silver) would have been far too expensive do not hold up. What does scan, however, is that the garment had to be stage worthy: it had to meet performance requirements, if not the street requirements of the Sumptuary Laws. Specifically, the actor had to be able to move comfortably in a flexible, flowing, durable robe which could be packed for touring and cleaned as needed, would stand up under close inspection in daylight, could be recycled as repertory changed, and would appear sufficiently timeless so as not to characterize as outmoded the actor wearing it. Two modern textile historians, Maria Hayward and Santina Levey, have been most generous in offering advice on this enigmatic garment, and their deep knowledge of sixteenth-century fabrics and construction methods has been invaluable. ${ }^{33}$ Both thought that budget might have affected Henslowe's choice 'as some of the best options would have been expensive' - 'a hideous amount', as Levey puts it. Since, however, Henslowe did have access to some very expensive fabrics, Hayward suggests five possibilities for the 'invisibell' robe:

1. Cloth of silver (i.e., a silk cloth, probably with a complex weave producing a pattern, and incorporating metal-wrapped threads of metal wire) would have had a pale, shimmering quality, while cloth of gold, of a warmer quality, would have produced the same shimmering effect. Such cloth would have been especially effective if seen in candlelight, but the difficulty with cloth of silver is that it would be a fairly stiff fabric and thus not drape very well.

2. A range of lighter-weight fabrics with metal thread such as tinseled satins were more fashionable in the late fifteenth and early sixteenth centuries, but still might have been available.

3. Black velvet is certainly a possibility but as with the cloth of silver it would be quite heavy. If the company favoured black, Henslowe might have opted for a slightly lighter-weight silk such as a black satin, which has a natural shine because of the weave structure.

4. A 'shot' fabric ('shot through' with a warp of one colour and the weft of another) would have given a very changeable effect visually. 
5. Some of the cheaper options would have included taking a light-weight linen or silk fabric and painting or staining it; the large group of painter-stainers working in England could have produced a painted textile of this type. Staining would have been preferable because it would have produced a more flexible fabric since the colour stains the fibres rather than layering paint on the textile surface.

Levey, who has an excellent eye for stage performance, is convinced that the robe 'won't be in tissue or other fancy fabrics - it must relate to blending into the background - but how I don't know'. Changeable warp and woof (shot through) fabric, she notes, is fragile, very expensive, not very mobile, and unresponsive to the fluid movements of an actor's body. It is also a showy fabric: perhaps not the textile of choice for an actor going invisible or vanishing. Levey rather favors black, perhaps black silk velvet, which is quite light but also quite expensive at 20 s to a narrow 22-inch width in the late sixteenth century. Another very expensive but impressive option would be a 'good' or 'true' black wool, the price dependent on the quality of dye or, as prized at the top of the scale, pure black wool from a black sheep, whose value is immortalized in the 'Ba, ba, black sheep' nursery rhyme.

With no little humility at Hayward and Levey textile scholarship, I cast my lot with black as the colour of 'invisibell' choice, the intent being to blend in rather than stand out. The garment need not be plain. As Hayward observes, 'Good or true black was expensive and it made an excellent foil for jewellery... . Black was elegant and when embellished with ornate self-coloured embroidery, guards, slashing and passementerie it was far from understated'. ${ }^{34}$ Further, I probably would suggest to Henslowe that his robe 'to goo invisibell' be a ropa de letrado, a learned man's robe, which 'appears in Alcega's [1589] treatise with layouts for both cloth and silk'. The robe is floor length with the top of the sleeve forming a large puff and 'a very full semi-circular back which hangs in soft folds'; the hood, also laid out in Alcega's pattern, is a close-fitting cowl with neckband and foot-long closed hood in the back. The pattern 'takes $4 \frac{1}{2}$ Castilian baras ( 4 yards $4 \frac{1}{2}$ inches) of cloth 2 baras (66 inches) wide', which places such a garment within reasonable financial perimeters. ${ }^{35}$ More importantly, however, the learned man's robe is timeless and iconic, connoting respect, suggesting miracle or magic: a fluid, graceful garment to cloak the actor's body as he renders himself invisible. 


\section{Notes}

1 Martin Stevens and A.C. Cawley (eds), The Towneley Plays, 2 vols (Oxford, 1994), 2: 615. All Towneley references are to this edition.

2 Stephen Spector (ed), The N-Town Play, Cotton MS Vespasian D.8, 2 vols (Oxford, 1991). All N-Town references are to this edition.

3 Barbara D. Palmer, 'Cycling through High Water to Hell', festschrift in honor of David Mills, Medieval English Theatre, forthcoming 2009.

4 For example, the ark would be approximately 153 metres long, 26 metres broad, and fifteen metres high, dimensions which probably would attract Noah's attention. American readers will remember comedian Bill Cosby's 1963 album Bill Cosby is a Very Funny Fellow: Right! with its routines on 'Noah: Right!', 'Noah: And the Neighbor', and 'Noah: Me and You, Lord'. After the Lord delivers his lengthy ark instructions, an exceedingly long silence finally is punctured by Cosby's benumbed 'What's a cubit?'

5 The angels are plural ('cantabunt angeli): they may be more than two, an entire choir, visible or invisible; the miracle is in the music and its almost summoning Christ to raise the lid of the tomb chest and rise up.

6 'An Iconography for Swearers: The Almondbury Passion Poem', The Early Drama, Art, and Music Review 12 (1989), 9-16.

7 See Philip Butterworth, Magic on the Early English Stage (Cambridge, 2005), 77-9, which cites Reginald Scot's 1584 Discouerie of Witchcraft for details of juggling boxes and also includes the remarkable notes and tomb cover diagram from Volume of Secrets.

8 Alan C. Dessen, Recovering Shakespeare's Theatrical Vocabulary (Cambridge, 1995), $196-215$.

9 Francis B. Brévart, 'Between Medicine, Magic, and Religion: Wonder Drugs in German Medico-Pharmaceutical Treatises of the Thirteenth to the Sixteenth Centuries', Speculum 83:1 (January 2008), 27. Brévart further cites pulverized snake '(Whoever holds this powder in the naked hand cannot be seen by anyone for as long as he keeps his hand closed)' and '[t]he (unidentified) plant belecolis, [which] when kept inside the mouth or in a secret place on one's person, was also alleged to make the individual invisible' (n. 84, 27-8).

10 My thanks to Alan Dessen and Leslie Thomson for drawing these instances to my attention. 
11 The unmistakable modern authority on how all of these effects were or could be performed is Philip Butterworth. See his Theatre of Fire: Special Effects in Early English and Scottish Theatre (London, 1998) and Magic on the Early English Stage.

12 David Mills (ed), The Chester Mystery Cycle: A New Edition with Modernized Spelling (East Lansing, 1992), 348. Also see Mills, Recycling the Cycle: The City of Chester and Its Whitsun Plays (Toronto, 1998), 167, which notes 'some lifting device [in 'The Ascension'] which allows Christ to be suspended at particular points on the ascent to engage in sung dialogue with the two angels above, in what seems to have been a visible heaven'.

13 See Francesc Massip, 'The Cloud: A Medieval Aerial Device, Its Origins, and Its Use in Spain Today', The Early Drama, Art, and Music Review 16 (1994), 65-77; Pamela M. King and Asunción Salvador-Rabaza, 'La Festa d'Elx: The Festival of the Assumption of the Virgin, Elche (Alicante)', Medieval English Theatre 8 (1986), 28-50; Pamela M. King, 'Elche Again - The Venida and Semana Santa', Medieval English Theatre 12 (1990), 4-20; and Clifford Davidson, 'Falling and Rising on the Medieval Stage', Technology, Guilds, and Early English Drama (Kalamazoo, 1996), 81-100.

14 Barbara D. Palmer, The Early Art of the West Riding of Yorkshire (Kalmazoo, 1990), 143-4. Brotherton Library, University of Leeds, Ripon Ms F.R.19, mb 1d.

15 The performance text is almost identical to Matthew 17:2: 'And [He] was transfigured before them: and his face did shine as the sun, and his raiment was white as the light... . And, behold, there appeared unto them Moses and Elias talking with him... . While [Peter] yet spake, behold, a bright cloud overshadowed them: and behold a voice out of the cloud, which said, This is my beloved Son, in whom I am well pleased; hear ye him. And when the disciples heard it, they fell on their face, and were sore afraid. And Jesus came and touched them, and said, Arise, and be not afraid. And when they had lifted up their eyes, they saw no man, save Jesus only'.

16 R.M. Lumiansky and David Mills (eds), The Chester Mystery Cycle, 2 vols (Oxford, 1974 and 1986), 1: 388. All Chester references are to this edition. The translation is from Mills, Chester... Modernized, 367.

17 Donald C. Baker, John L. Murphy, and Louis B. Hall, Jr. (eds), 'The Conversion of St. Paul', The Late Medieval Religious Plays of Bodleian MSS Digby 133 and E Museo 160 (Oxford, 1982), SD before 1. 412, SD after 1. 501.

18 Alan C. Dessen and Leslie Thomson in A Dictionary of Stage Directions in English Drama, 1580-1642 (Cambridge, 1999), 144, see the Histriomastix mist as probably literal, but Butterworth thinks it 'not a literal requirement but a metaphoric one that is concerned with producing mystification' (Magic, 77). See Butterworth, Magic, 81-2, on pyrotechnical sophistication with flaming, presumably coloured images of 
knights jousting in the air, hart and boar hunting, and a battle between St. George and the Dragon.

19 Barbara D. Palmer, 'Staging the Virgin's Body: Spectacular Effects of Annunciation and Assumption', The Early Drama, Art, and Music Review 21.2 (1999), 63-80; reprinted in Clifford Davidson (ed.), The Dramatic Tradition of the Middle Ages (New York, 2004), 155-72.

20 Peter Meredith and John E. Tailby (eds), The Staging of Religious Drama in Europe in the Later Middle Ages: Texts and Documents in English Translation (Kalamazoo, 1983), 244-5.

21 Dessen and Thompson, Dictionary, 121, 209-10, 242.

22 The Folger Theatre's highly-touted 2008 production of Macbeth was such a blend of play, fun, and cleverness in its treatment of the spirit world. Directed by Aaron Posner, the play's widely-publicized use of 'magic' was conceived by Teller, the silent half of the magic team Penn and Teller, well known to Las Vegas audiences. Although The Washington Post (10 February 2008, R20) trumpeted 'that some of the most famous illusions associated with the history of magic acts have been adapted here', the production's 'magic' relied on deception, distraction, sound, reversal of audience expectation, clever blocking, mirror and light effects (explicated by Butterworth in Magic, 80-1), and other very effective but hardly original stage devices.

23 Household books of the period specifically instruct how to make empty but gorgeously decorated dishes for show and other dishes for consumption in order to fill the banquet table in an attractive, impressive manner. The kitchen post of waferer was not a menial rank.

24 Butterworth, Magic, 83, addresses the revolving table, one of which was sturdy enough to support two St. Bartholomews, presumably flayed and unflayed.

25 R.A. Foakes (ed), Henslowe's Diary, $2^{\text {nd }}$ edition (Cambridge, 2002), 325. Foakes annotates Nembia's gown as 'unexplained'.

26 For example, in 1 Henry IV 5.1.12, 'You have deceived our trust/ And made us doff our easy robes of peace'; or Shrew 1.2.131, 'And offer me disguised in sober robes/ To old Baptista as a schoolmaster'.

27 Maria Hayward, Dress at the Court of King Henry VIII. The Wardrobe Book of the Wardrobe of the Robes prepared by James Worsley in December 1516, edited from Harley MS 2284, and his Inventory prepared on 17 January 1521, edited from Harley MS 4217, both in the British Library (Leeds, 2007), 103-5.

28 Janet Arnold (ed), Queen Elizabeth's Wardrobe Unlock'd. The Inventories of the Wardrobe of Robes prepared in July 1600 edited from Stowe MS 557 in the British Library, MS LR 2/121 in the Public Record Office, London, and MS V.b.72 in the Folger Shakespeare Library, Washington DC (Leeds, 1988), 52. 
29 Janet Arnold, Patterns of Fashion: The cut and construction of clothes for men and women c1560-1620 (London, 1985), 3.

30 Janet Arnold. A Handbook of Costume (London, 1973).

31 Arnold, Queen Elizabeth's Wardrobe Unlock'd, 158.

32 Jenny Tiramani, 'Janet Arnold and the Globe Wardrobe: Handmade Clothes for Shakespeare's Actors', Costume: A Volume for Janet Arnold 34 (London, 2000), 118.

33 Maria Hayward is Director of the AHRC [Arts and Humanities Research Council] Research Centre for Textile Conservation and Textile Studies at the University of Southampton. Santina M. Levey is the former Keeper of the Department of Textiles and Dress at the Victoria and Albert Museum. Both are Fellows of the Society of Antiquaries. Their excerpted and paraphrased opinions above are from Maria Hayward's 15 January 2008 e-mail to me, Santina Levey's 26 October 2007 letter to me, and my 29 February 2008 telephone call to her.

34 Hayward, King Henry VIII, 11.

35 Arnold, Patterns of Fashion, 6. 